\title{
UJI KUALITAS PAKAN KOMPLIT BERBASIS HIJAUAN SORGUM-INDIGOFERA UNTUK INDUK DOMBA PROLIFIK
}

\section{THE QUALITY TEST OF COMPLETE FEED BASED ON SORGHUM-INDIGOFERA FORAGE FOR PROLIFIC EWES}

\author{
RACHMAT SOMANJAYA ${ }^{1 *}$, AAF FALAHUDIN ${ }^{1}$, DULMAJID ${ }^{2}$ \\ ${ }^{1}$ Program Studi Peternakan, Fakultas Pertanian Universitas Majalengka \\ ${ }^{2}$ Alumni Program Studi Peternakan, Fakultas Pertanian Universitas Majalengka \\ *e-mail : rachmat.somanjaya@unma.ac.id
}

\begin{abstract}
The study aims to evaluate the quality and digestability value of complete feed based-on sorghumindigofera forage as substitution of field grass for prolific ewes. The research was conducted experimentally in the laboratory through proximat and in vitro tests. Three experimental feed compositions are SII (60\% sorghum forage silage $+30 \%$ Indigofera forage hay $+10 \%$ rice bran $)$; SI2 (50\% sorghum forage silage $+40 \%$ Hay forage Indigofera $+10 \%$ rice bran); SI3 (40\% sorghum forage silage $+50 \%$ Indigofera forage Hay $+10 \%$ rice bran); and 100\% grass field (FG) as control. The observed ingredients are the value of nutrient content and feed nutrient digestibility. The data from the obtained proximat test results were analyzed and translated descriptively and compared based on standard feed references for prolific ewes from NRC-Canada. Meanwhile, the digesting value data was analyzed with the ANOVA test and further tested with Duncan's multiple range test (DMRT). The results showed that the overall nutrient content of SI feed can compensate for FG. In fact, the crude protein content and gross energy of SI feed is higher than FG according to the amount of hay indigofera given in rations. Si feed digestability values were higher $(p<0.05)$ than $F G$, and all the feed tested had a higher nutrient content than the NRC standard. it can be concluded that the complete feed based on forage sorghum and indigofera (SI) has a higher quality than field grass and the NRC recommendation for prolific ewes and can be used as feed as a substitute for field grass. In addition, the complete feed composition SII (60\% sorghum forage silage $+30 \%$ indigofera hay $+10 \%$ fine bran) is an ideal complete feed for prolific arrowroot sheep.
\end{abstract}

Keywords: sorghum-indigofera, prolific ewes, nutrient content, digestibility value

\begin{abstract}
ABSTRAK
Penelitian ini bertujuan untuk mengevaluasi kualitas dan nilai kecernaan pakan komplit berbasis hijauan sorgum dan indigofera sebagai pengganti rumput lapangan untuk induk domba prolifik. Penelitian dilakukan secara eksperimental di laboratorium melalui uji proksimat dan in vitro. Tiga komposisi pakan percobaan yaitu SI1 (60\% silase hijauan Sorgum $+30 \%$ hay hijauan Indigofera $+10 \%$ dedak padi); SI2 (50\% silase hijauan Sorgum $+40 \%$ Hay hijauan Indigofera $+10 \%$ dedak padi); SI3 (40\% silase hijauan Sorgum $+50 \%$ Hay hijauan Indigofera $+10 \%$ dedak padi); dan RL (100\% rumput lapangan) sebagai kontrol. Peubah yang diamati yaitu nilai kandungan nutrien dan kecernaan pakan. Data hasil uji proksimat yang diperoleh dianalisis dan diterjemahkan secara deskriptif dan dibandingkan berdasarkan acuan standar pakan untuk induk domba bunting dan menyusui dengan potensi kelahiran kembar dari NRC-Canada. Sedangkan, data nilai kecernaan dianalisis dengan uji ANOVA dan diuji lanjut dengan uji jarak berganda Duncan. Hasil penelitian menunjukan bahwa kandungan nutrien pakan SI secara keseluruhan dapat mengimbangi RL. Bahkan, kandungan protein kasar dan energi bruto pakan SI lebih tinggi dari RL sesuai jumlah hay indigofera yang diberikan dalam ransum. Nilai kecernaan pakan SI lebih tinggi $(\mathrm{p}<0,05)$ dari RL, dan semua pakan yang diujikan memiliki kandungan nutrien lebih tinggi dari standar NRC. Dapat disimpulkan bahwa pakan komplit berbasis hijauan sorgum dan indigofera (SI) memiliki kualitas yang lebih tinggi dari rumput lapangan dan rekomendasi NRC untuk induk domba prolifik serta dapat dijadikan sebagai pensubstitusi rumput lapangan. Selain itu, komposisi pakan komplit SI1 (60\% silase hijauan sorgum $+30 \%$ hay indigofera $+10 \%$ dedak halus) merupakan pakan komplit ideal untuk induk domba garut prolifik.
\end{abstract}

Kata kunci: sorgum-indigofera, induk domba prolifik, kandungan nutrien, nilai kecernaan

\section{PENDAHULUAN}

Domba Garut sudah sangat dikenal dan menjadi sumber daya genetik ternak (SDGT) di wilayah Jawa Barat. Induk Domba Garut memiliki potensi sifat prolifik (mampu menghasilkan anak lebih dari satu ekor dalam satu kali kelahiran). Namun, Khotijah et al. 
(2015) melaporkan bahwa induk Domba Garut yang dipelihara pada peternakan rakyat dengan sistem pemeliharaan tradisional, jumlah anak sekelahirannya masih rendah (1,2ekor), tingkat kematian embrionya cukup tinggi (30\%) dan kemampuan bertahan hidup selama periode prasapihnya antara $20-70 \%$. Salah satu faktor yang mempengaruhinya adalah pakan yang biasa diberikan, yaitu rumput lapangan dengan kualitas rendah.

Kualitas rumput lapangan sangat dipengaruhi oleh musim, rata-rata kandungan proteinnya hanya $7-9 \%$, nilai kecernaannya rendah (Telleng et al. 2017), dan serat kasarnya tinggi $(21,24 \%)$ (Somanjaya et al. 2016). Kondisi itu akan berpengaruh kurang baik terhadap performa produksi atau pun reproduksi induk Domba Garut. Upaya peningkatan kualitas pakan dengan cara menambahkan konsentrat, secara ekonomis tentunya kurang menguntungkan karena harganya mahal dan ketersediaan di pasaran cukup sulit.

Peningkatan kualitas pakan dengan cara memilih komoditi tanaman yang memiliki kandungan gizi yang baik, tahan terhadap cekaman panas dan kebutuhan terhadap airnya sedikit sangat dianjurkan untuk diterapkan pada usaha pembibitan domba. Hal tersebut dimaksudkan supaya kontinuitas ketersediaan pakan berkualitas baik dapat terjamin sepanjang musim dan memiliki nilai manfaat terhadap kelestarian lingkungan.

Beberapa jenis tanaman yang direkomendasikan adalah sorgum dan indigofera. Tanaman sorgum merupakan jenis serealia, sedangkan indigofera adalah jenis tanaman kacang-kacangan (Leguminosa). Kedua tanaman tersebut memiliki keunggulan sesuai dengan kriteria yang diharapkan tersebut.

Hijauan sorgum memiliki kandungan protein kasar dan serat kasar masing-masing sebanyak $7,82 \%$ dan $28,94 \%$. Kandungan nutrien tersebut lebih tinggi jika dibandingkan rumput gajah yang mengandung protein kasar sebanyak $6 \%$ dan serat kasarnya $34,25 \%$, serta pucuk tebu yang memiliki kandungan protein kasar dan serat kasarnya masing-masing sebanyak 5,33\% dan 35,48\% (Purnomohadi 2006).
Kandungan protein hijauan indigofera cukup tinggi setara dengan alfalfa berkisar 28-31\% dan mineral $(\mathrm{Ca}, \mathrm{P}, \mathrm{Mg}, \mathrm{Zn})$ yang optimum bagi ternak dengan kandungan tannin rendah dan kandungan beta carotene tinggi (Rizki Palupi et al. 2014). Abdullah et al. (2012) menyatakan bahwa Indigofera dapat meningkatkan produksi susu dan mengurangi penggunaan pakan komersil pada kambing.

Kombinasi bahan pakan antara hijauan sorgum dan indigofera sangat berpotensi untuk meningkatkan performa produksi dan reproduksi induk Domba Garut. Namun, berapa banyak komposisi perpaduan dan bagaimana cara mengolah serta mengawetkan kedua jenis hijauan tersebut sehingga dapat mencapai kandungan gizi yang diinginkan belum banyak dikaji lebih dalam. Dalam penelitian ini penulis akan menganalisis kandungan nutrien dan membandingkan beberapa perpaduan komposisi bahan pakan hijauan sorgum dan indigofera serta membuat teknik pengolahan dan pengawetan pakan dengan cara silase dan hay. Harapan dari hasil penelitian ini adalah diperolehnya komposisi perpaduan jenis hijauan sorgum dan indigofera yang ideal (sesuai anjuran National Research Council/NRC) untuk meningkatkan performa produksi dan reproduksi induk Domba Garut prolifik.

\section{MATERI DAN METODE \\ Materi dan Lokasi Penelitian}

Penanaman sorgum dan indigofera dilaksanakan pada Bulan Agustus sampai dengan September 2021, dan berlokasi di Kabupaten Majalengka, Provinsi Jawa Barat, Indonesia yang terletak pada titik koordinat $6^{\circ} 48^{\prime} 50.0^{\prime \prime S} 108^{\circ} 13^{\prime} 35.8^{\prime \prime E}$. Suhu rata-rata di daerah penelitian berkisar antara $21^{\circ}-35^{\circ} \mathrm{C}$, kelembapan 66 - 86\% dan berada pada ketinggian $141 \mathrm{~m}$ dpl (Bappeda Kabupaten Majalengka 2014). Uji kandungan nutrien pakan (Proksimat dan In Vitro) dilakukan di Laboratorium Terpadu Fakultas Peternakan IPB University Bogor - Indonesia.

Kandungan nutrien dan nilai kecernaan pakan dianalisis dengan uji proksimat dan in vitro. Dua jenis bahan pakan yang akan diuji yaitu 1) rumput lapangan (pakan 
konvensional); dan 2) pakan percobaan. Pakan percobaan merupakan perpaduan antara silase hijauan sorgum + hay hijauan indigofera + dedak padi dengan komposisi berbeda. Jenis hijauan sorgum yang digunakan adalah sorgum manis Varietas Samurai 1 yang dikeluarkan oleh Badan Tenaga Nuklir Nasional (BATAN) pada Tahun 2014. Asal-usul sorgum Varietas Samurai ini adalah dari Galur Zh-30 yang diradiasi sinar gamma dosis 30 Gy (Batan 2014). Varietas indigofera yang dipakai dalam penelitian ini adalah Indigofera zollingeriana dan dipanen setiap 50 hari. Keunggulan Indigofera zollingeriana adalah merupakan tanaman pakan sumber protein dengan produksi daun dan ranting edible 51 ton BK/ha/tahun (Abdullah 2014).

Komposisi perpaduan bahan pakan percobaan dibuat secara trial and error selanjutnya dilakukan pengujian kandungan nutriennya di laboratorium. Hasil yang terbaik adalah kandungan nutriennya yang mendekati anjuran dari NRC untuk induk domba prolifik. Adapun uji invitro adalah untuk menguji nilai kecernaan nutrien pakan yang diamati. Acuan kandungan nutrien pakan untuk induk domba disajikan dalam Tabel 1 berikut :

Tabel 1. Acuan Kandungan Nutrient Pakan Induk Domba (Bahan Kering)

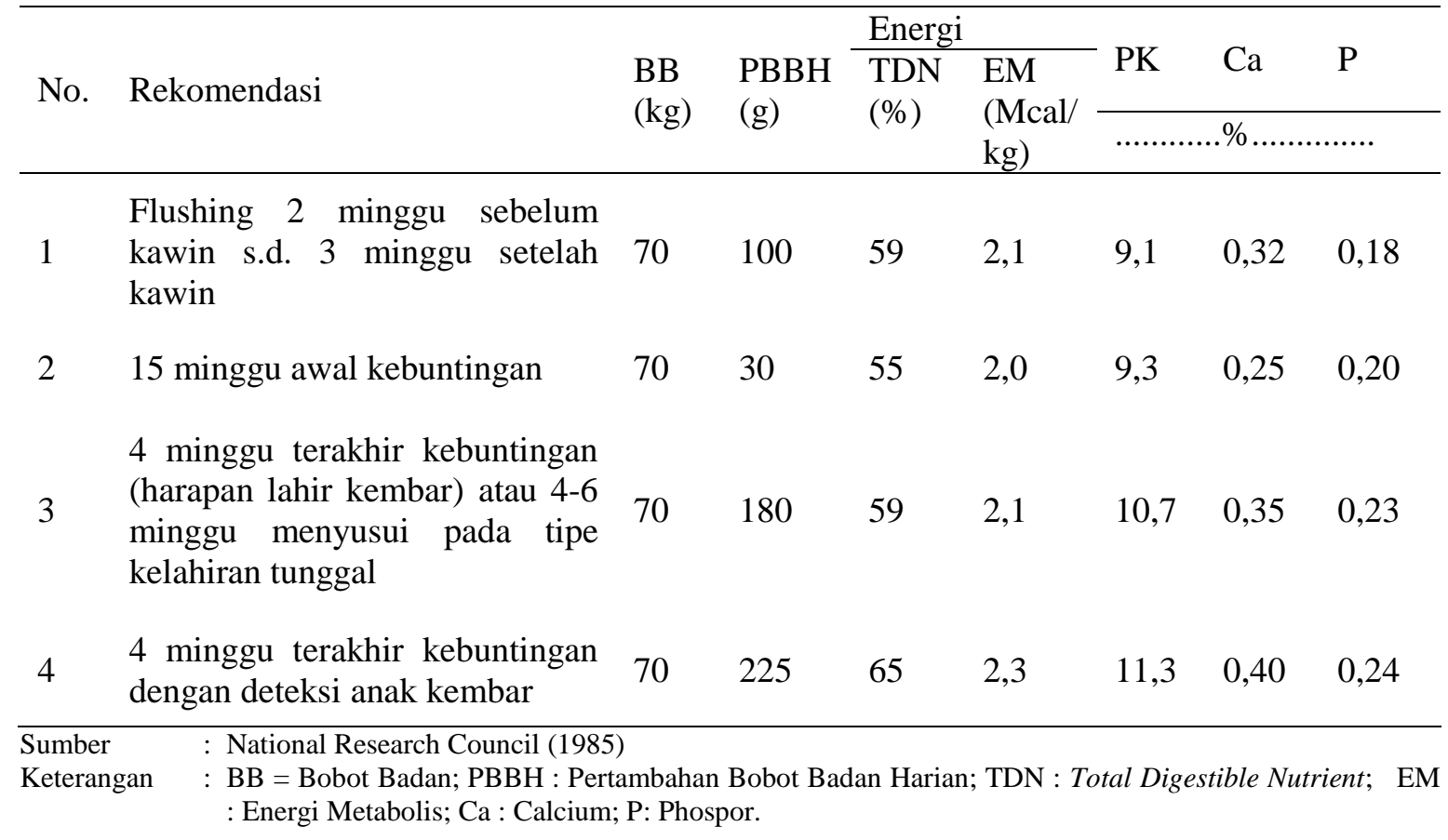

\section{Rancangan Percobaan}

Bahan yang akan diuji terdiri dua jenis pakan yaitu rumput lapangan (pakan konvensional) dan pakan percobaan hijauan sorgum dan indigofera (SI). Pakan percobaan terdiri dari tiga komposisi berbeda dengan tiga jenis bahan pakan yang sama yaitu silase hijauan sorgum, hay indigofera, dan dedak padi sebagai bahan pakan aditif. Total sampel pakan yang diuji adalah sebanyak empat macam dan pengujiannya diulang masing- masing sebanyak lima kali. Empat jenis komposisi pakan tersebut yaitu :

RL : 100\% rumput lapangan (kontrol);

SI1 : kombinasi $60 \%$ silase hijauan sorgum $+30 \%$ hay hijauan indigofera $+10 \%$ dedak padi;

SI2 : kombinasi $50 \%$ silase hijauan sorgum $+40 \%$ hay hijauan indigofera $+10 \%$ dedak padi; dan 
SI3 : kombinasi $40 \%$ silase hijauan sorgum $+50 \%$ hay hijauan indigofera $+10 \%$ dedak padi.

\section{Variabel yang Diamati}

Variabel yang diukur dari empat macam sampel pakan dalam penelitian ini adalah bahan kering (BK), abu, protein kasar (PK), lemak kasar (LK), serat kasar (SK), bahan ekstrak tanpa nitrogen (BETN), gross energy (GE), total digestible nutrient (TDN), calcium $(\mathrm{Ca})$, dan phopor $(\mathrm{P})$ melalui uji Proksimat Wendee (AOAC 2005). Sedangkan kecernaan bahan kering (KcBK), kecernaan bahan organik $(\mathrm{KcBO})$, kecernaan protein kasar (KcPK), dan kecernaan serat kasar (KcSK) diuji secara in vitro.
Data kandungan nutrien pakan disajikan secara deskriptif dan dibandingkan dengan standar acuan nutrien pakan untuk induk domba bunting yang berpotensi dengan kelahiran kembar dari National Research Council. Selanjutnya, data nilai kecernaan nutrien pakan dianalisis dengan analisis sidik ragam (ANOVA) dan diuji lanjut dengan uji jarak berganda Duncan. Data yang diperoleh diolah menggunakan program SPSS versi 25 (SPSS Inc., Chicago, IL).

\section{HASIL DAN PEMBAHASAN \\ Kandungan Nutrien}

Rincian kandungan nutrien pakan percobaan dan rumput lapangan disajikan dalam Tabel 2. berikut:

\section{Analisis Data}

Tabel 2. Kandungan Nutrien Rumput Lapangan dan Beberapa Komposisi Pakan Komplit Berbasis Hijauan Sorgum dan Indigofera

\begin{tabular}{|c|c|c|c|c|c|c|c|c|c|c|}
\hline \multirow{2}{*}{$\begin{array}{c}\text { Jenis } \\
\text { Pakan }\end{array}$} & $\mathrm{BK}$ & Abu & PK & SK & LK & BETN & $\mathrm{Ca}$ & $\mathrm{P}$ & TDN & \multirow{2}{*}{$\begin{array}{c}\mathrm{GE} \\
\mathrm{Kal} / \mathrm{g}\end{array}$} \\
\hline & \multicolumn{9}{|c|}{ ㄴ.1, } & \\
\hline RL & 30,88 & 11,89 & 12,60 & 22,90 & 2,18 & 41,31 & 0,83 & 0,45 & 66,26 & 3.396 \\
\hline SI 1 & 21,42 & 8,86 & 12,62 & 31,81 & 3,61 & 49,49 & 0,99 & 0,45 & 59,92 & 4.291 \\
\hline SI 2 & 26,45 & 10,34 & 19,82 & 30,57 & 1,91 & 46,86 & 1,48 & 0,56 & 59,35 & 4.423 \\
\hline SI 3 & 34,62 & 9,69 & 19,43 & 30,00 & 4,34 & 44,09 & 1,42 & 0,39 & 56,12 & 4.393 \\
\hline
\end{tabular}

Keterangan : RL $=$ Rumput Lapangan; SI $1=60 \%$ silase hijauan sorgum $+30 \%$ hay indigofera $+10 \%$ dedak halus; SI $2=50 \%$ silase hijauan sorgum $+40 \%$ hay indigofera $+10 \%$ dedak halus; SI $3=40 \%$ silase hijauan sorgum $+50 \%$ hay indigofera $+10 \%$ dedak halus; BK $=$ Bahan Kering; PK $=$ Protein Kasar; SK = Serat Kasar; LK = Lemak Kasar; BETN = Bahan Ekstrak Tanpa Nitrogen; $\mathrm{Ca}=$ Kalsium; $\mathrm{P}=$ Phosfor; $\mathrm{GE}=$ Gross Energy

Kandungan nutrien pakan sangat berpengaruh terhadap performa reproduksi ternak. oleh karena itu, peternak harus mengetahui dan memahami cara membuat formulasi pakan yang sesuai dengan kebutuhan ternak supaya memperoleh hasil yang baik. Wina dan Susana (2013) menyampaikan bahwa performa produksi dan reproduksi ternak akan menunjukan hasil yang baik jika diberikan pakan dengan kandungan nutrien yang baik pula. Salah satu kandungan nutrien yang paling berperan dalam pakan adalah energi. Tur et al. (2017) menambahkan bahwa selain faktor energi, protein dan asam amino dalam pakan sangat penting untuk pertumbuhan, metabolisme dan reproduksi ternak. Hasil penelitiannya menunjukan bahwa domba lokal Anatolia yang diberi pakan dengan tingkat protein berbeda dapat mempengaruhi respon ovarium (jumlah folikel dominan dan corpus luteum) dan pemulihan embrio (embrionic recovery) yang dihitung berdasarkan jumlah folikel dan 
corvus luteum yang diharapkan untuk pemulihan.

Rendahnya nutrien yang diterima oleh induk ruminansia akan berdampak terhadap berhentinya proses reproduksi. Hal yang akan segera terjadi sebagai akibat dari buruknya nutrisi yang diterima tersebut adalah terganggunya siklus reproduksi (Scaramuzzi et al. 2006). Meskipun daya adaptasi domba lebih baik dibanding dengan ruminansia lainnya, respon induk domba terhadap keseimbangan energi negatif (negative energy balance, $N E B$ ) yaitu terjadinya durasi anestrus yang semakin lama, menurunnya fertilitas, dan meningkatnya kematian embrio (Butler 2000; Hess et al. 2005; Forcada dan Abecia 2006; Diskin dan Morris 2008).

Melalui pemberian pakan dengan kuantitas dan kualitas yang stabil, diharapkan dapat meningkatkan performa reproduksi induk domba. Beberapa hasil penelitian sebelumnya menyatakan bahwa dari masingmasing bahan pakan hijauan sorgum dan $I$. Zollingeriana dapat meningkatkan performa reproduksi ruminansia. De Castro et al., (2013) melaporkan bahwa induk domba Santa Ines yang diberi penambahan silase sorgum untuk tujuan meningkatkan kandungan energi pakan hingga lebih dari 2,0 Mcal kg-1 BK dapat meningkatkan performa reproduksi di akhir masa kebuntingan dan di masa laktasi. Sedangkan Suharlina et al., (2016) menyatakan bahwa nilai kecernaan pakan yang mengandung $I$. Zollingeriana lebih tinggi dibanding dengan kontrol $(0 \%$ I. Zollingeriana) dan untuk kambing maksimum penggunaannya sebanyak $20 \%$.

\section{Analisis Kandungan Bahan Kering}

Kandungan bahan kering (BK) dari rumput lapangan (RL) lebih tinggi dibanding dengan pakan komplit berbasis hijauan sorgum dan indigofera (SI) pada setiap komposisi, kecuali SI3. Kondisi tersebut menunjukan pula bahwa kandungan air pada pakan RL lebih tinggi dan bahan kering pada pakan SI berkorelasi dengan tingkat penambahan hay indigofera. Bahan kering menjadi patokan utama dalam standar pemberian jumlah pakan kepada ternak. Jayanegara (2012) menyatakan bahwa bahan kering dipergunakan untuk membandingkan kualitas antar bahan pakan. Selain itu, dengan diketahuinya kandungan bahan kering pakan, maka akan diketahui nilai stabilitas kualitas pakan jika dilakukan penyimpanan dalam jangka waktu lama. Jika pakan disimpan dalam jumlah kadar air diatas standar penyimpanan, maka bahan pakan tersebut akan mudah tercemari mikroba yang menghasilkan racun (mycotoxin) yang berbahaya bagi ternak atau manusia yang mengkonsumsi hasil produknya.

\section{Analisis Kandungan Abu}

Abu merupakan sisa pembakaran dalam tanur pada temperatur $400-600^{\circ} \mathrm{C}$ yang di dalamnya terkandung zat-zat anorganik atau mineral (Agustono et al. 2017). Kadar abu pada rumput lapangan lebih tinggi dari pada pakan percobaan SI. Semakin tinggi komposisi hay indigofera dalam ransum, kadar abunya cenderung semakin tinggi. Kondisi tersebut menunjukan bahwa kandungan bahan organik pada ransum SI semakin tinggi, dan merupakan indikator nilai kecernaan pakan yang tinggi.

\section{Analisis Kandungan Protein Kasar}

Semua zat yang mengandung nitrogen diartikan sebagai protein kasar. Rata-rata kandungan nitrogen dalam protein adalah sebanyak $10 \%$ atau pada kisaran $13-19 \%$ (Jayanegara 2012). Kandungan protein rumput lapangan lebih lebih rendah dari pakan SI pada semua komposisi kecuali SI1 yaitu sama-sam memiliki kandungan protein kasar sekitar $12 \%$. Berbeda halnya dengan pendapat Jayanegara (2012) yang menyatakan bahwa rumput lapangan memiliki kandungan protein kasar rendah yaitu dibawah $10 \%$. Hal ini diduga karena sampel rumput lapangan saat pengujian dilakukan pada saat awal musim hujan, dan rumput yang dianalisis lebih banyak bagian rumput muda. Kandungan protein kasar pakan SI berkorelasi dangan tingkat penambahan hay indigofera ke dalam ransum. Diketahui bahwa kandungan protein kasar hay indigofera dalam penelitian ini adalah sebanyak $27,78 \%$. Kandungan protein kasar tersebut mendekati hasil penelitian Palupi et al. (2014) bahwa kandungan protein kasar tepung daun dan pucuk indigofera adalah sebanyak $28,98 \%$. Kandungan protein kasar pada jenis pakan yang diuji dalam 
penelitian ini lebih tinggi dari standar rekomendasi NRC (National research Council 1985) untuk induk domba yang berpotensi melahirkan anak kembar.

\section{Analisis Kandungan Serat Kasar dan Bahan Ekstrak Tanpa Nitrogen (BETN)}

Serat kasar dan BETN merupakan bagian dari karbohidrat, dan karbohidrat juga dapat dipisahkan berdasarkan jenis zat gula yang terdiri atas monosakarida, disakarida, trisakarida, dan polisakarida. Pati adalah jenis gula polisakarida yang merupakan sumber energi yang baik, sedangkan selulosa yang di dalamnya berisi heksose (zat gula) dan terdapat dalam serat kasar, merupakan sumber energi yang rendah. Bagi hewanhewan berperut tunggal selulosa tidak dapat dicerna, namun bagi ruminansia dengan bantuan bakteri rumen, baik selulosa atau pun hemiselulosa dapat dicerna secara enzimatik (Tillman et al. 1991).

Kandungan serat kasar dan BETN dalam pakan percobaan (SI) lebih tinggi dari pada RL. Hal tersebut memungkinkan tingkat kecernaan pakan SI akan lebih tinggi dibandingkan RL. Tillman et al. (1991) menyatakan bahwa BETN berisi zat-zat mono, di, tri, dan polisakarida terutama pati yang mudah larut dalam cairan asam dan basa dalam analisis serat kasar dan mempunyai daya cerna yang tinggi.

\section{Analisis Kandungan Lemak Kasar}

Kandungan lemak kasar sering juga disebut dengan istilah ekstrak eter, karena bahan makanan dianalisis melalui ekstraksi dengan menggunakan pelarut lemak (eter), dan hasil yang diperoleh berupa lemak atau lipida (Tillman et al. 1991). Pendapat lainnya menyatakan bahwa lipida adalah sekelompok zat-zat yang tidak larut dalam air tetapi larut dalam eter, kloroform, dan benzena. $\mathrm{Ke}$ dalam golongan zat-zat tersebut termasuk lemak, fosfatida, sterol, dan lain-lainnya (Anggorodi 1985).

Kandungan lemak dalam ransum percobaan SI pada penelitian ini menunjukan angka yang cenderung lebih tinggi kecuali pada SI2. Kandungan lemak kasar pada pakan SI memiliki nilai yang lebih tinggi diduga karena dalam komposisinya mengandung $10 \%$ dedak padi. Upaya untuk mencegah ketengikan pakan yang bersumber dari dedak padi, di dalam penelitian ini dedak padi diambil dari tempat penggilingan padi setiap dua minggu sekali atau paling lama disimpan selama satu bulan.

\section{Analisis Kandungan Mineral (Ca dan P)}

Bahan permulaan yang digunakan untuk determinasi mineral adalah abu yang diperoleh dari hasil analisis proksimat. Kandungan mineral yang umum disampaikan dalam standar kualitas pakan termasuk dalam rekomendasi dari National research Council yaitu hanya kalsium $(\mathrm{Ca})$ dan Phosfor (P). Ca dan $\mathrm{P}$ termasuk ke dalam kategori mineral makro.

Kandungan mineral $\mathrm{Ca}$ dan $\mathrm{P}$ pada komposisi pakan SI2 menunjukan angka tertinggi, baik dibandingkan dengan RL atau pun pakan SI lainnya. Hay indigofera terlihat memiliki peran terhadap perubahan kandungan mineral tersebut. Abdullah (2014) melaporkan hasil penelitiannya bahwa kandungan mineral $\mathrm{Ca}$ dan $\mathrm{P}$ pada tepung daun dan cabang edible masing-masing sebanyak 2,04 dan $0,46 \%$.

\section{Analisis Kandungan Total Nutrien Tercerna (TDN/Total Digestible Nutrient)}

Kandungan TDN pada hasil penelitian ini menunjukan bahwa RL lebih tinggi dari pada rasum SI di semua komposisi. Hal ini diduga karena bahan penyusun ransum SI dipanen pada umur cukup tua (sorgum 70 hari setelah tanam dan indigofera 60 hari setelah tanam/panen sebelumnya). Sehingga kandungan ligninnya cukup tinggi sebagai akibat dari banyaknya serat kasar dan batang yang sudah berkayu pada indigofera.

\section{Analisis Kandungan Energi}

Energi adalah suatu bentuk kerja atau perubahan dari energi kimia dalam bentuk molekul bahan makanan menjadi kinetik dari suatu reaksi metabolik yang menghasilkan panas. Panas yang diproduksi hewan berasal dari oksidasi zat organik bahan makanan yang disuplai, dan dapat dijadikan sumber energi. Akibatnya, nilai energi yang dihasilkan dapat dijadikan kriteria nilai gizi pakan atau ransum yang dikonsumsi hewan tersebut. Pembakaran makanan tersebut menggunakan oksigen (O2) dan menghasilkan energi bruto atau gross energi 
(GE). Pengukuran energi bahan makanan ternak atau ransum menggunakan satuan kalori (kal) yaitu jumlah panas yang dibutuhkan untuk meningkatkan temperatur 1 gram air dari suhu $14.5^{\circ} \mathrm{C}$ menjadi $15.5^{\circ} \mathrm{C}$ (Jayanegara 2012). Sementara, energi metabolis (EM) diperoleh berdasarkan perhitungan dari seluruh energi yang diperoleh dari makanan dikurangi energi yang hilang dalam feses, urine, dan pembakaran gas-gas (Anggorodi 1985).

Kandungan energi pada jenis pakan percobaan (SI) untuk semua komposisi lebih tinggi dibanding dengan RL. Perbedaan tertinggi yaitu antara komposisi pakan SI2 dengan RL dengan selisih sebanyak 1.027 $\mathrm{kal} / \mathrm{g}$. Hal tersebut menunjukan bahwa pakan SI dapat memberikan dampak lebih baik terhadap performa produksi atau pun reproduksi. Kandungan energi yang tinggi dalam pakan atau ransum dapat membuat hewan sanggup melakukan suatu pekerjaan dan proses-proses produksi lainnya (Anggorodi 1985).

\section{Nilai Kecernaan Pakan}

Secara keseluruhan nilai kecernaan pakan SI pada semua komposisi menunjukan nilai yang lebih baik $(\mathrm{p}<0,05)$ jika dibandingkan dengan nilai kecernaan RL. Komposisi pakan SI2 (50\% silase hijauan sorgum $+40 \%$ hay indigofera $+10 \%$ dedak halus) memiliki nilai kecernaan paling tinggi, kecuali pada nilai kecernaan serat kasarnya. Namun, nilainya tidak jauh berbeda dibanding dengan SI1 atau SI3. Nilai kecernaan bahan kering (KcBK) tertinggi (SI2) dalam penelitian ini lebih baik dibanding dengan $\mathrm{KcBK}$ silase kombinasi $50 \%$ hijauan sorgum $+50 \%$ gamal hasil penelitian Kurniawan et al. (2019) yaitu $71,74 \%$ : 65,81\%. Demikian pula dengan nilai kecernaan bahan organik (KcBO), perbandingan nilainya yaitu $69,30 \%$ : $64,11 \%$. Salah satu faktor penyebab tingginya $\mathrm{KcBK}$ dan $\mathrm{KcBO}$ pakan SI diduga karena tingginya nilai $\mathrm{KcBK}$ dan $\mathrm{KcBO}$ dari hay indigofera. Hasil penelitian Abdullah (Abdullah 2014) menunjukan bahwa nilai $\mathrm{KcBK}$ dan $\mathrm{KcBO}$ dari daun dan batang edible Indigofera zollingeriana masing-masing sebanyak $78-82 \%$ dan $77 \%$.

Rincian perbandingan nilai kecernaan antara RL dan pakan komplit SI disajikan dalam Tabel 3 berikut :

Tabel 3. Nilai Kecernaan (In Vitro) Rumput Lapangan dan Beberapa Komposisi Pakan Komplit Berbasis Hijauan Sorgum dan Indigofera

\begin{tabular}{|c|c|c|c|c|}
\hline \multirow{2}{*}{ Jenis Pakan } & $\mathrm{KcBK}$ & $\mathrm{KcBO}$ & $\mathrm{KcPK}$ & $\mathrm{KcSK}$ \\
\hline & \multicolumn{4}{|c|}{..$\%$} \\
\hline RL & $67.15 \pm 0,74^{\mathrm{a}}$ & $63.97 \pm 0,91^{\mathrm{a}}$ & $46.84 \pm 0,12^{\mathrm{a}}$ & $40.48 \pm 0,18^{a}$ \\
\hline SI 1 & $71.47 \pm 0,81^{\mathrm{b}}$ & $68.36 \pm 0,91^{\mathrm{b}}$ & $51.46 \pm 0,30^{\mathrm{b}}$ & $43.44 \pm 0,27^{\mathrm{b}}$ \\
\hline SI 2 & $71.74 \pm 0,32^{\mathrm{b}}$ & $69.30 \pm 0,38^{\mathrm{b}}$ & $53.03 \pm 0,58^{\mathrm{c}}$ & $44.95 \pm 0,67^{\mathrm{b}}$ \\
\hline SI 3 & $70.66 \pm 0,75^{\mathrm{b}}$ & $67.41 \pm 0,69^{b}$ & $52.98 \pm 0,26^{\mathrm{c}}$ & $45.13 \pm 0,51^{\mathrm{b}}$ \\
\hline
\end{tabular}

Keterangan : KcBK $=$ Kecernaan Bahan Kering; $\mathrm{KcBO}=$ Kecernaan Bahan Organik; KcPK $=$ Kecernaan Protein Kasar; KcSK = Kecernaan Serat Kasar; RL $=$ Rumput Lapangan; SI $1=60 \%$ silase hijauan sorgum $+30 \%$ hay indigofera $+10 \%$ dedak halus; SI $2=50 \%$ silase hijauan sorgum + $40 \%$ hay indigofera $+10 \%$ dedak halus; SI $3=40 \%$ silase hijauan sorgum $+50 \%$ hay indigofera $+10 \%$ dedak halus; Superscript berbeda pada kolom yang sama menunjukan perbedaan nyata $(\mathrm{p}<0,05)$.

Nilai kecernaan bahan kering secara linier berpengaruh terhadap nilai kecernaan lainnya. Sehingga nampak bahwa setiap kenaikan kecernaan bahan kering, relatif akan diikuti oleh naiknya nilai kecernaan lainnya. Nilai kecernaan makanan sangat mempengaruhi kecepatan pengeluaran makanan tersebut dari saluran pencernaan. Kecepatan pengeluaran makanan dari saluran 
pencernaan dipengaruhi oleh absorpsi bahan makanan dan kecepatan aliran bahan makanan yang tidak dapat dicerna. Artinya bahwa nilai kecernaan makanan berhubungan erat juga dengan tingkat konsumsi makanan (Tillman et al. 1991).

\author{
dari National Research Council (NRC) \\ untuk Induk Domba Prolifik
}

Kesesuaian kandungan nutrien jenis dan komposisi pakan yang diamati dalam penelitian ini dengan rekomendasi dari NRC disajikan dalam Tabel 4 berikut :

Kesesuaian Kandungan Nutrien Jenis Pakan Percobaan dengan Rekomendasi

Tabel 4. Kesesuaian Kandungan Nutrien Antara Pakan RL dan SI dengan Rekomendasi dari NRC untuk Induk Domba Prolifik

\begin{tabular}{|c|c|c|c|c|c|}
\hline \multirow{2}{*}{ Nutrien } & \multicolumn{4}{|c|}{ Perlakuan } & \multirow{2}{*}{ NRC } \\
\hline & RL & SI 1 & SI 2 & SI 3 & \\
\hline Energy Metabolis (EM) (Mcal/Kg) & 2.40 & 2.20 & 2.10 & 2.00 & 2.10 \\
\hline Protein Kasar (PK) $(\%)$ & 12.60 & 12,62 & 19.82 & 19.43 & 10.70 \\
\hline Total Digestible Nutrient (TDN) (\%) & 66.26 & 59.92 & 59.35 & 56.12 & 59.00 \\
\hline Calcium (Ca) (\%) & 0.83 & 0.99 & 1,48 & 1.42 & 0.35 \\
\hline Posphor $(\mathrm{P})(\%)$ & 0.45 & 0.45 & 0.56 & 0.39 & 0.23 \\
\hline
\end{tabular}

Keterangan : RL $=$ Rumput Lapangan; SI $1=60 \%$ silase hijauan sorgum $+30 \%$ hay indigofera + $10 \%$ dedak halus; SI $2=50 \%$ silase hijauan sorgum $+40 \%$ hay indigofera $+10 \%$ dedak halus; SI $3=40 \%$ silase hijauan sorgum $+50 \%$ hay indigofera $+10 \%$ dedak halus; NRC = National Research Council (1985).

Perhitungan energi metabolis diketahui melalui perhitungan energi tercerna atau Digestible Energy (DE) terlebih dahulu (Tillman et al. 1991). Rangakaian penghitungannya adalah sebagai berikut :

$$
\begin{aligned}
\mathrm{DE}(\mathrm{Kcal} / \mathrm{kg})= & \mathrm{TDN} / 100 \times 4409 \mathrm{Kcal} \\
\mathrm{EM}(\mathrm{Kcal} / \mathrm{kg})= & \mathrm{DE} \times \quad 0,82 \quad \text { (untuk } \\
& \text { ruminansia) }
\end{aligned}
$$

Melalui penggunaan rumus tersebut, maka diperoleh data energi metabolis seperti yang terlihat pada Tabel 4.

Kesesuaian kandungan nutrient berdasarkan data pada Tabel 4. menunjukan bahwa semua jenis dan komposisi pakan memiliki kandungan nutrient lebih tinggi dari rekomendasi NRC. Namun, jika dilihat berdasarkan angka terdekat, maka komposisi pakan komplit SI1 merupakan pakan yang paling mendekati rekomendasi NRC untuk induk domba prolifik.

\section{KESIMPULAN}

Dapat disimpulkan bahwa pakan komplit berbasis hijauan sorgum dan indigofera (SI) memiliki kualitas yang lebih tinggi dari rumput lapangan dan rekomendasi NRC untuk induk domba prolifik serta dapat dijadikan pakan sebagai pensubstitusi rumput lapangan. Selain itu, komposisi pakan komplit SI1 $(60 \%$ silase hijauan sorgum + $30 \%$ hay indigofera $+10 \%$ dedak halus) merupakan pakan komplit ideal untuk induk domba garut prolifik.

\section{DAFTAR PUSTAKA}

ABDULLAH L. 2014. Prospektif agronomi dan ekofisiologi Indigofera zollingeriana sebagai tanaman penghasil hijauan pakan berkualitas tinggi. Pastura J Trop Forage Sci. 3(2):79-83. doi:10.24843/Pastura.2014.v03.i02.p06.

ABDULLAH L, APRIASTUTI D, APDINI TAP. 2012. Use of Indigofera zollingeriana as a forage protein source in dairy goat rations. Di dalam: Proc. Asia dairy Goat Conference Malaysia. hlm 71-72.

AGUSTONO B, MA'RUF A, LAMID M, 
PURNAMA MTE. 2017. Identification of Agricultural and Plantation Byproducts as Inconventional Feed Nutrition in Banyuwangi. J Med Vet. 1(1):12-22.

https://www.researchgate.net/publicatio $\mathrm{n} / 322095385$.

ANGGORODI. 1985. Ilmu Makanan Ternak Umum. Ed ke-3. Jakarta: PT. Gramedia. http://permimalang.wordpress.com/200 7/12/12/aspergillus-niger/.

AOAC. 2005. Official Methods of Analysis of AOAC International.

BAPPEDA KABUPATEN MAJALENGKA. 2014. Kondisi Geografis Kabupaten Majalengka. Di dalam: Data Sektoral Kabupaten Majalengka. Majalengka: Bappeda Kabupaten Majalengka. hlm $1-9$.

BATAN. 2014. Deskripsi sorgum samurai 1. Jakarta.

http://benihbatan.blogspot.co.id/search/l abel/Deskripsi Varietas.

BUTLER WR. 2000. Nutritional interactions with reproductive performance in dairy cattle. Di dalam: Animal Reproduction Science. Volume ke-60-61.

DE CASTRO FAB, DE AZAMBUJA RIBEIRO EL, MIZUBUTI IY, DA SILVA LDDF, DE FREITAS BARBOSA MAA, MARSON B, GRANDIS FA, JUNIOR FF, PEREIRA ES. 2013. Dietary energy in late pregnancy and during lactation and performance of Santa Inês sheep in an accelerated mating system. Semin Ciências Agrárias. 34(6):4187-4202. doi:10.5433/16790359.2013v34n6Supl2p4187.

DISKIN MG, MORRIS DG. 2008. Embryonic and Early Foetal Losses in Cattle and Other Ruminants. Reprod Domest Anim. 43 SUPPL.2. doi:10.1111/j.1439-0531.2008.01171.x.

FORCADA F, ABECIA JA. 2006. The effect of nutrition on the seasonality of reproduction in ewes. Di dalam: Reproduction Nutrition Development. Volume ke-46.

HESS B, LAKE S, SCHOLLJEGERDES E, WESTON T, NAYIGIHUGU V, MOSS G. 2005. Nutritional controls of beef cow reproduction. $J$ Anim Sci. 83 suppl_13.

doi:10.2527/2005.8313_supplE90x.

JAYANEGARA A. 2012. Pengetahuan Bahan Makanan Ternak. Bogor: CV Nutri Sejahtera. http://anuragaja.staff.ipb.ac.id/files/201 2/04/Buku-PBMT.pdf.

KHOTIJAH L, WIRYAWAN KG, SETIADI MA, ASTUTI DA. 2015. Reproductive performance, cholesterol and progesterone status of garut ewes fed ration containing different levels of sun flower oil. Pakistan J Nutr. 14(7):388391. doi:10.3923/pjn.2015.388.391.

KURNIAWAN W， SYAMSUDDIN S, SALID WL, ISNAINI PD. 2019. Evaluasi Kualitas, Karakteristik Fermentasi dan Kecernaan In Vitro Silase Campuran Sorgum Stay GreenGliricidia sepium dengan Penambahan Berbagai Level Asam Laktat. J Agripet. 19(2):99-106. doi:10.17969/agripet.v19i2.14857.

NATIONAL RESEARCH COUNCIL. 1985. Nutrient Requirements of Sheep. Washington, D.C. https://books.google.co.id/books?hl=id $\& 1 \mathrm{r}=\& \mathrm{id}=\mathrm{hcbPz} 4 \mathrm{AfdoEC} \&$ oi $=$ fnd $\& \mathrm{pg}=$ $\mathrm{PR} 1 \& d q=$ Nutrient + Requirements + of $+\mathrm{S}$ heep\&ots $=$ v59imKP3Uo\&sig $=$ NO7Qw roUCAFpF0UwC254PPEdpCw\&redir esc $=\mathrm{y} \# \mathrm{v}=$ onepage $\& \mathrm{q}=$ Nutrient Requirements of Sheep \&f=false.

PALUPI RIZKI, ABDULLAH L, ASTUTI DAS. 2014. Potential and utilization of Indigofera sp shoot leaf meal as soybean meal substitution in laying hen diets. J Ilmu Ternak dan Vet. 19(3):210-219. doi:10.14334/jitv.v19i3.1084.

PALUPI R, ABDULLAH L, D A A, SUMIATI. 2014. Potensi dan pemanfaatan tepung pucuk Indigofera sp . sebagai bahan pakan substitusi bungkil kedelai dalam ransum ayam petelur. J Ilmu Ternak dan Vet. 19(3):210-219.

PURNOMOHADI M. 2006. Potensi Penggunaan Beberapa Varietas Sorgum Manis (Sorghum bicolor (L. Moench) Sebagai Tanaman Pakan. J Hayati. 12:41-44.

SCARAMUZZI RJ, CAMPBELL BK, 
DOWNING JA, KENDALL NR, KHALID M, MUÑOZ-GUTIÉRREZ M, SOMCHIT A. 2006. A review of the effects of supplementary nutrition in the ewe on the concentrations of reproductive and metabolic hormones and the mechanisms that regulate folliculogenesis and ovulation rate. Reprod Nutr Dev. 46(4):339-354. doi:10.1051/rnd:2006016.

SOMANJAYA R, RAHMAH UIL, DANI U. 2016. Performa dan Daya Cerna Domba Garut Jantan Terhadap Penambahan Fermentasi Limbah Hijauan Sorgum Ke Dalam Ransum. CR J. 02(02):147-162.

SUHARLINA S, ASTUTI DA, NAHROWI N, JAYANEGARA A, ABDULLAH L. 2016. In Vitro Evaluation of Concentrate Feed Containing Indigofera zollingeriana in Goat. $J$ Indones Trop Anim Agric. 41(4):196-203. doi:10.14710/jitaa.41.4.196-203.

TELLENG M, WIRYAWAN KG, KARTI PDMH, PERMANA IG, ABDULLAH L. 2017. Silage quality of rations based on in situ sorghum-indigofera. Pakistan J Nutr. 16(3):168-174. doi:10.3923/pjn.2017.168.174.

$\begin{array}{llr}\text { TILLMAN AD, HARTADI } & \mathrm{H}, \\ \text { REKSOHADIPRODJO } & \mathrm{S}, \\ \text { PRAWIROKUSUMO } & \mathrm{S}, \\ \text { LEBDOSOEKOJO S. 1991. Ilmu }\end{array}$ Makanan Ternak Dasar. Ed ke-5. Tillman AD, editor. Yogyakarta: Gadjah Mada University Press.

TUR İ, DÍNÇ DA, SEMACAN A. 2017. Protein based flushing related blood urea nitrogen effects on ovarian response, embryo recovery and embryo quality in superovulated ewes. Theriogenology. 98:62-67. doi:10.1016/j.theriogenology.2017.05.0 02.

WINA E, SUSANA IWR. 2013. Manfaat lemak terproteksi untuk meningkatkan produksi dan reproduksi ternak ruminansia. $J$ War. 23(4):176-184. https://core.ac.uk/download/pdf/236128 227.pdf. 